\title{
Economic Potential Of Moringa Oleifera As A Commercial Tree Species And Its Suitability For Forest Management Intervention In Taungya Farming System
}

\author{
*Ajayi, C. A., Williams, O. A., Famuyide, 0. 0 and Adebayo, 0. \\ Forestery research institute of Nigeria, PMB 5054, Ibadan \\ *Corresponding Author: chris07ng@yahoo.com
}

\begin{abstract}
This paper examined economic potentials of Moringa oleifera as commercial tree specie and its suitability for forest management intervention in Taungya farming system with a view to reviewing the objective in the Nigeria case study. Ibadan is the capital city of Oyo state, Nigeria and the second largest city in Africa. Results/ inferences drawn were primary data generated from FRIN research annual report and was used to rather establish quantitative relationships in an effort to provide a comparative account on the performance of Moringa oleifera in native and introduced ranges. Secondary data from two (2) research papers reporting rigorous scientific data on arable crop productivity in agroforestry combinations systems from Southwest (i.e. introduced range) and Kano state representing northern region (i.e. native range) of Nigeria were revaluated and analyzed. Findings suggest that growing and processing moringa leaves would require an illustrated guidebook that should contain the emphasis on cultivation; harvesting and transportation; processing the leaves; packaging and storage; and using Moringa leaves for nutrition. The standards, together with a code of good practices and an inspection guide, should be adhered to guaranty the good sanitary and nutritional status of the product especially for moringa leaf powder while emphasizes the need for more clinical studies to obtain acceptance of Moringa as a nutritional food supplement among the international scientific community. While prospects of farm forestry/ taungya potential to develop the Moringa oleifera processing and increase value addition to improve welfare of society is gradually assuming a significant position due to high land to man ratio factor. It is recommended that taungya-combined production of forestry and moringa tree lagricultural crops on forest lands be advocated. The taungya system always exhibited certain basic attributes and required some preconditions for its adoption. The preconditions, such as land hunger and low standard of living of the population, are clearly socioeconomic in nature. There is little economic validation of the farming systems described herein. Socioeconomic considerations should however be of high priority on any further research agenda. Evaluation of social acceptability of these practices by farmers should be a major consideration in the process of technology generation. Although numerous studies have been conducted on the Moringa oleifera (Miracle Tree), few address the social role of the resource, and its contribution to the reduction of the rural poverty. Therefore, a cursory look on the leading edge perspectives, science and application in terms of economic potentials of Moringa oleifera as a commercial tree species generally is encouraged for further research studies in Nigeria.
\end{abstract}

Keywords: Moringa oleifera; Economic production; farm forestry; taungya; Sub-SaharaAfrica 


\section{INTRODUCTION}

Survey findings revealed that natural resources are being over-exploited at an unsustainable rate and inevitably, an even greater overall area has now been deforested and natural biodiversity lost (Anadu and Oates, 1982) and according to a 2004 report by the African Development Bank (AFDB), annual losses in West Africa varies. State forest reserves are under government control in which government is supposed to limit settlement and manage the forest (and the exploitation of its products) in the best interests of the state and its people (Anadu and Oates, Ibid.). The emphasis of forest management was to sustain timber yields in perpetuity. But as far back as 1980s, it was reported that "Working Plans" to achieve this were being abandoned for uncontrolled and intensive exploitation (Anadu and Oates, Ibid.). They also reported that the taungya system of farming was largely being abused. (Taungya farming is a farming system where farmers are given temporary farming rights in return for planting commercial tree species. As these trees grow, the farmers are expected to move on, after obtaining several harvests from their crops (Oates, 1999).This paper examines economic potential of Moringa oleifera as a commercial tree species and its suitability for forest management intervention in Taungya farming system with a view to reviewing the objective in the Nigeria case study.

\section{Challenges to the development of Moringa oleifera's suitability for Forest Management Intervention in Taungya Farming Systems in Nigeria}

Feeding the world's population is one of the most pressing challenges facing humanity in the twenty-first century. FAO (2011) estimates that 925 million people in the world are food insecure, representing around one in six of the world's population. Forests as well as trees on farms are a direct source of food and cash income for more than a billion of the world's poorest people, providing both staple foods and supplemental foods such as fruits, edible leaves and nuts. Moringa oleifera is one of such example of direct source of food and cash income today.

Moringa (Moringa oleifera, Moringaceae) is possibly the planet's most valuable undeveloped tree, at least in humanitarian terms; yielding protein, oil, and carbohydrates, and with a load of vitamins and minerals, (National Research Council, 2006). Related Species have been noted, out of the 13 Moringa species only Moringa oleifera has been accorded research and development. The rest remain almost unknown to science. As a sort of food market on a stalk, it yields at least four different edibles: pods, leaves, seeds and roots. And beyond edibles, it provides products that make village life more self-sufficient: lubricating oil, lamp oil, wood, paper, liquid fuel, skin treatments, the means to purify water, and more.

Essentially, the demand for food depends on population and the dietary habits/per capita daily calorie intake of the people under consideration. On the other hand, the food requirement of the nation is dependent on an additional factor namely; food import and export balance. Consequently, there are basically three ways to produce this food requirement; through rain-fed agriculture, irrigated agriculture and food import. Over $90 \%$ of Nigeria's agricultural output comes from peasant farmers who dwell in the rural area where $60 \%$ of the population live. The vast 
majorities of these farmers have limited access to modern inputs, let alone land and other productive resources and are unlikely to have access to pesticides, fertilizers, hybrid seeds and irrigation without some form of public sector intervention. It is also significant to state that the majority of these resource poor farmers are women.

According to a 1993 report by Parotta (1993), Moringa oleifera, in its native range, grows in secondary dry tropical deciduous forests in association with Albizia procera (Roxb.) Benth., Bombax malabaricum DC., Dalbergia sissoo Roxb., Ficus glomerata Roxb., Gmelina arborea Linn., Kydia calycina Roxb., and Lagerstremia parviflora Roxb. (Agrawal et. al, 1986; Champion, 1936) on which available data reported to have been valued mainly for its edible fruits, leaves, flowers, roots, and seed oil and is used extensively in traditional medicine throughout its native and introduced ranges (Booth and Wickens, 1988; Jahn, et. al, 1986; Morton,1991; Nautiyal and Venhataraman, 1987). The results, therefore, can be generalized only within the limits of the data presented. Yet another problem encountered in this respect is the fact that some trials lacked proper treeless control plots in the experimental design; and in a few cases where such control plots were included, due to constraints in the plot layout plan, statistical analysis were impossible. Variations in the population of intercrops (compared to forestry tree crops) owing to the presence of tree components in the system is a potential confounding factor in this respect. This calls for further and more careful field experimentation on aspects relating to the commercial suitability of Moringa oleifera field crops in tree-crop combinations, besides the need for having more refined statistical approaches so that cause-effect perspectives on mixed species production could be deduced.

\section{Study Area}

\section{METHODOLOGY}

The study area is Oyo state. The state is situated in the southern-western part of the country between latitude $7^{\circ} 23^{\prime} \mathrm{N}$ and $3^{\circ} 54^{\prime} \mathrm{E}$. It is bounded by Ogun state on the South, Kwara state on North, Republic of Benin on the west and Osun state on the east. (Microsoft Encarta, 2009). Ibadan is situated in tropical rainforest zone in Nigeria with average rainfall distribution of $1250 \mathrm{~mm}$. The vegetation is bounded in the North by the derived Savannah (Adebayo et al., 2004). Ibadan, Oyo state is chosen as study site because of its age long practice of taungya system that several research institutes in the state affords it. The site also ranked oldest from desk reviewed as one out of the seven states in Southwest Nigeria that are predominantly agrarian. The major agricultural produce in the Southwestern Nigeria, include: Oryza sativa (Rice), Zea mays ( Maize), vigna sp (Cowpea), Manihot sp.(Cassava), Dioscorea sp.(Yam), musa sp. (Plantain/ Banana), Citrus sp. (Orange), Theobroma sp.(Cocoa ), Saccharium sp.( Sugar cane), Ananas sp (Pineapple), Carica sp.(Pawpaw), Kola sp. (Kola nut), Elaeis sp. (Oil palm) (Odeyinka and Ajayi, 2004).

The focus on the Taungya farming system in the present paper was an attempt to find out its suitability in FRIN Agroforestry plot in Ibadan. Moringa oleifera, as is currently advocated in this paper is premised on at its infancy stage and not enough data has been generated yet as to draw a 
general conclusion of its suitability as a prominent example of agroforestry that include systems of historical significance such as shifting cultivation and the taungya, amongst myriad of agroforestry systems and practices. Therefore, the present study was largely exploratory in character, with no confirmatory or predictive aims set. Primary data generated from Forestry Research Institute of Nigeria (FRIN), research annual report was used to rather establish quantitative relationships in an effort to provide a comparative account on the performance of Moringa oleifera in native and introduced ranges. Secondary data from two (2) research papers reporting rigorous scientific data on arable crop productivity in agroforestry combinations systems from Southwest (i.e. introduced range) and Kano state representing northern region (i.e. native range) of Nigeria were revaluated and analyzed. Results/ inference drawn are discussed below.

\section{Database of experimental studies}

\section{RESULTS AND DISCUSSION}

It has been argued that taungya interventions make environmentally sound land management easier to engage in, that their economic returns are more apparent. The secondary data however, do not reflect the full spectrum of agroforestry practices across the region and Table 1 in the appendix is only an attempt to drive home the increasing need to further consider associated forest cover trials. Following recent research by Torimiro, et al. (2009) in their study database on respondents' perception of Moringa oleifera has succeeded in providing salient information on perception about Moringa oleifera according to farmers' gender in Southwestern Nigeria. The study revealed ten perceptional statements, which were validated and presented to the respondents for their responses against a likert scale ranging from strongly agree to strongly disagree. Data presented in appendix 1 section showed that $60.0 \%$ and $20.0 \%$ of the male and female respondents, respectively, strongly agreed that Moringa oleifera is of great economic importance. The challenge now is to find ways to integrate the new knowledge with the knowledge that farmers already have, so that widespread adoption of its suitability as a commercial tree species for forest management intervention in Taungya farming (agroforestry) system will improve the welfare of farmers today, as well as the prospects for sustainable economic growth in the future. It is hoped that this paper will contribute towards that objective.

\section{Ethnobotanical Potentials of Moringa oleifera as a Commercial Tree}

Generative propagation of Moringa oleifera seeds was sourced from St. Anne's Anglican Grammar School, Molete, Ibadan and reported to germinate three days after seeds were broadcasted in FRIN, Ibadan. The seedlings were transferred into poly pot of different potting medium (top soil, river sand and Gmelina saw- dust) a week after planting. Germination percentage, girth height and number of leaves per seedlings were among parameters observed every week during nursery practices for two months. The seedlings were later transplanted on a plot (30m x $27 \mathrm{~m})$ already occupied by arable crops (cassava and maize) at different spacing; 
$0.5 \mathrm{~m} \times 0.5 \mathrm{~m}, 1 \mathrm{~m} \times 1 \mathrm{~m}, 1.5 \mathrm{~m} \times 1.5 \mathrm{~m}$. Results show that different potting media of Top soil, River sand and Gmelina sawdust gave a progressive germination rate with percentage of $95 \%, 82 \%$, and $68 \%$ respectively after eight weeks. Results showed a better performance of seedlings observed under Top soil and River sand media respectively. The highest girth height of $14 \mathrm{~cm}$ was observed under Top soil medium while Gmelina saw dust medium gave the least Girth height of $10 \mathrm{~cm}$ after 8 weeks. These figures clearly reveal that Gmelina saw dust medium was indicative of low germination rate but it is essential that further research will consider Pine saw dust medium. From the foregoing, further research was discontinued due to paucity of fund and problem of transportation.

\section{Exploring New management intervention to contain Global increase in the $21^{\text {st }}$ Century}

Projections by the World Bank suggest that the demand for all types of cereals will increase globally by 2.5 percent a year between 1990 and 2000 , and with rising incomes, fall to 2.3. Fruits and vegetables production increased significantly during the last 20 years probably in relation to the growing urbanization, but also in response to change in the diet, even in rural areas. The sudden acceleration of vegetable production in the early 1980s correspond to the drought period when the Governments decided to promote small-scale irrigation projects, mostly based on shallow groundwater, in order to offset the cereal production deficit due to the drought. It is remarkable to note that vegetable production is twice as much as the rice production.

Contributing author submitted that growing vegetables can help address the "hidden hunger" of micronutrient deficiencies that affects some 1 billion people worldwide (State of the World, 2011). The foregoing attested to the claims by Abdou Tenkouano, Director of AVRDC-The World Vegetable Center's Regional Center for Africa. In the same vein, it also brings multiple benefits for farmers. The fact that Vegetables have shorter cycles, are faster-growing than cereal crops, and require little space further suggest that well-planned improvement of taungya/ homestead gardens within town centres can boost commercial trading of Moringa oleifera leaf vegetables and also generate increased public sector investment for research institutes. Moringa oleifera (Miracle Tree) otherwise known as the horseradish or broomstick tree is a multipurpose tree. It is locally known as Zogall/ Zogalla-gandi in Hausa, Ikwe oyibo in Ibo and Ewe igbale/ Idagbo monoye in Yoruba ("the tree which grows crazily"). Moringa oleifera is extremely rich in vital nutrients and, as a bonus, can grow very fast in dry areas of the world, where food is scarce. Indian nutritonists have also published several articles demonstrating the efficiency of Moringa leaf powder, particularly against vitamin A deficiency (VAD) (Seshadri and Nambiar (2003); Nambiar, et al., 2003).

In the scope of Mti project intervention in the traditional cooked Moringa oleifera leaf trading in Kano State, the project coordinator submitted that the problem analysis worthy of intervention affects the overall Moringa oleifera leaf traditional value chain. Furthermore, the project concluded that some activities relating to farming of Moringa oleifera showed that $90 \%$ are dominated by old women and girls while the males' accounts for the remaining $10 \%$. On the other hand, retail activities of Moringa oleifera leaf in Kano state comprise vendors, hawkers of the 
product. The dealers of Moringa oleifera leaf encompass distribution activities that span from buying raw cook and supply (BRCS). The old women ranked highest with $40 \%$, this is followed by adolescent girls with 34\% while young girls followed closely with $25 \%$ and male use ranked least with 1\%. This result suggests that most of the female relative to their male counterparts were more involved in Moringa oleifera farming and trade.

Understanding the economic tools used to assess the viability of a long-term project such as farm forestry/ taungya is very important if a farmer is to make an informed investment decision. Understanding these tools also allows: (a) a farm forestry project to be evaluated against other investments, such as investing in the stock market or building a new dam; (b) the cash flow of a project to be assessed; (c) The financial aspects of the project to be analysed; and (d) the economic risks to be highlighted right from the start of the project.

While it may be argued that an economic analysis only considers the monetary aspects of a project, it does allow farmers to weigh up the financial costs and returns against non-economic benefits such as aesthetics, wildlife, erosion or salinity control.

The increasing proportion of the urban population expected to reach $63 \%$ of the national population in 2025 will significantly modify the socio-economic landscape of the nation. Major changes induced by urbanisation and by the resultant specialisation of the role of consumers/producers, will affect the diet: mostly wheat, rice and vegetables in the cities; traditional cereals, tubers and roots in the rural areas.

Current emerging issues of economic potential of Moringa oleifera as a commercial tree species suggest why it could play a role as a leading edge in the $21^{\text {st }}$ century as a veritable marketable product. With the advent of value chain addition to the production and marketing of Moringa product such as food supplement, Moringa leaf decoction drink, leafy vegetable eaten/leaf sap/poultice made from fresh leaves and juice from the leaves, among other are the ranges of farm products for sale that has been improved upon for Moringa while the increase in this type of treeplanting either as home garden, farm forestry or taungya farming system has also increased as a feasible way of protecting the environment. Unless a system is proven economical in the context of on-farm situations, it will not be adopted by the farming community. There is little economic validation of the farming systems described herein. Socio-economic considerations should however be of high priority on any further research agenda. Evaluation of social acceptability of these practices by farmers should be a major consideration in the process of technology generation. Although numerous studies have been conducted on the Moringa oleifera (Miracle Tree), few address the social role of the resource, and its contribution to the reduction of the rural poverty.

\section{Over-exploitation and High Human Pressure}

It is often suggested that it is poverty that compels people to over-exploit. It is true that in the absence of any alternative form of income, people revert to subsistence farming in order to sustain themselves. Over-exploitation and logging are invariably linked because logging activity creates the infrastructure facilitating access for over-exploitation and the transport of non-timber forest 
product such as Moringa oleifera towards urban centres. However, it is a consequence of weak law enforcement on timber extraction that suggested why people are now over-exploiting on a massive scale. State and local forest departments appear unable to control large scale illegal activities within their reserves and state forest reserves have become "commons".

Forest reserves in south-west Nigeria in particular are in effect, absorbing the poor or landless from other regions, an issue that never been seriously addressed. Tolerance of illegal activities (such as over-exploitation) leads to an influx of illegal immigrants, the establishment of illegal settlements and large scale clearing and forest conversion. In some instances, these activities (along with the establishment of plantations) have resulted in absolute destruction of all of the forest and the reserves have informally been de-gazetted. Illegal activities that culminate in land clearing and farming impact more on non-timber forest products status than logging activity per se ( personal communication). Another form of food-producing tree such as seen in Moringa oleifera and Sesbania grandiflora was reported by Adedire (2013) suggests case study dominated by home gardens in the Asian countries. Home gardens exemplify many agroforestry characteristics i.e. the intimate mix of diversified agricultural crops and multipurpose trees that fulfils most basic need of the local population. The rate at which the nutrient capital would run down, as removal exceeds input, will vary with different ecosystems. Although shifting cultivation may survive for some years to come, something of a crisis in man-land relations is developing in Nigeria. Pressure on land has already led to far-reaching changes in the agricultural economy, but there can be little doubt that further change is called for. There are four probable directions in which such changes may occur. First, evolution towards permanent cultivation of annual crops must almost certainly take place, perhaps via a "compound land", farming system as practiced in parts of eastern Nigeria. Secondly, there is likely to be continued increase in the acreage planted to tree crops, especially oil palm. This is an understandable if not entirely satisfactory development since tree-crop plantations provide assured cash income, are much less prodigal of land, and once established require less labour to maintain than annual-crop farms.

Thirdly, the number of farmers engaged in part-time trade and manufacturing and in plantation labour will continue to grow. Finally, the pressure of people on land remaining unabsorbed by these three kinds of changes will continue to seek an outlet in that long-established stand-by of an under-occupied rural labour force, migration - especially migration to the major urban areas.

\section{Economics of Production of Moringa Oleifera}

The most marketable parts of the moringa trees are the nursery seedlings, leaves, pods and seeds cake. (Plate 1 and 2). The leaves are dried and processed into powder (Plate 3 and 4). 


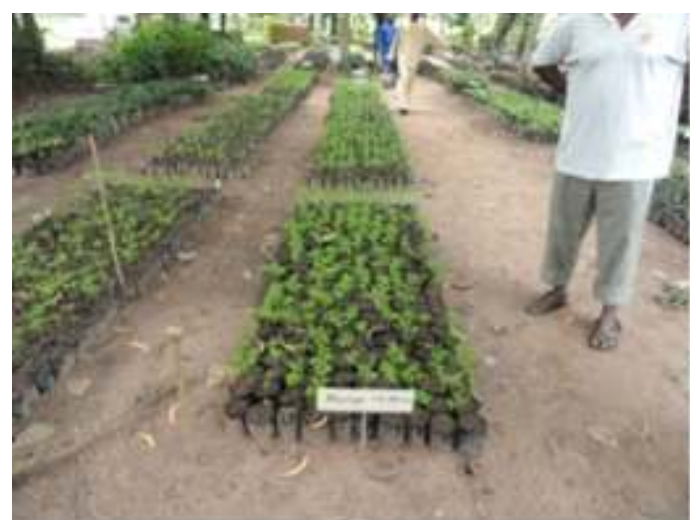

1

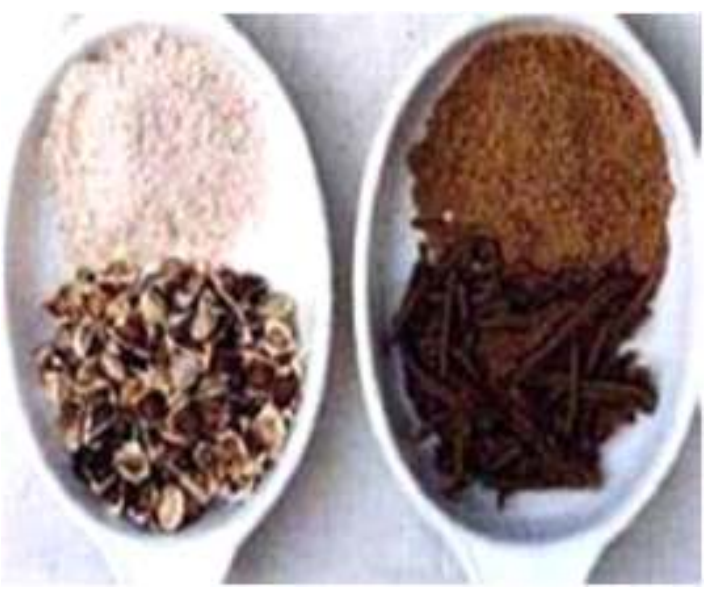

3

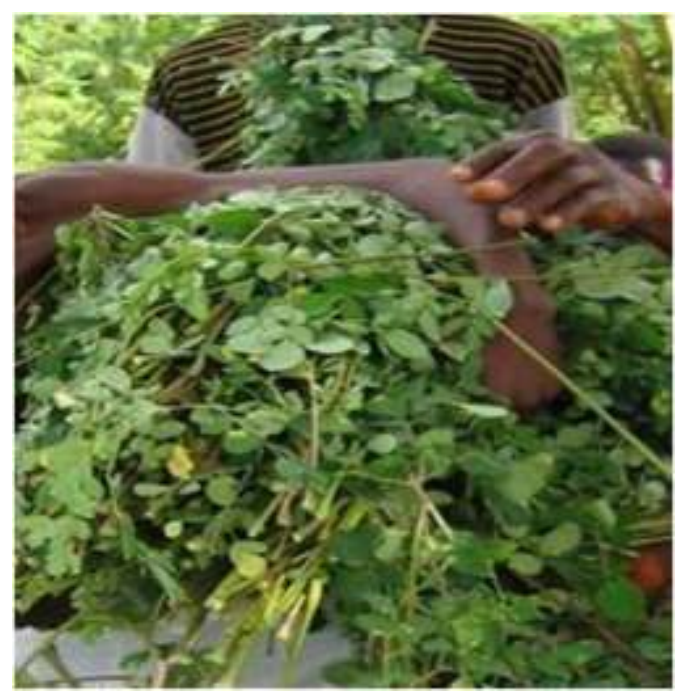

5

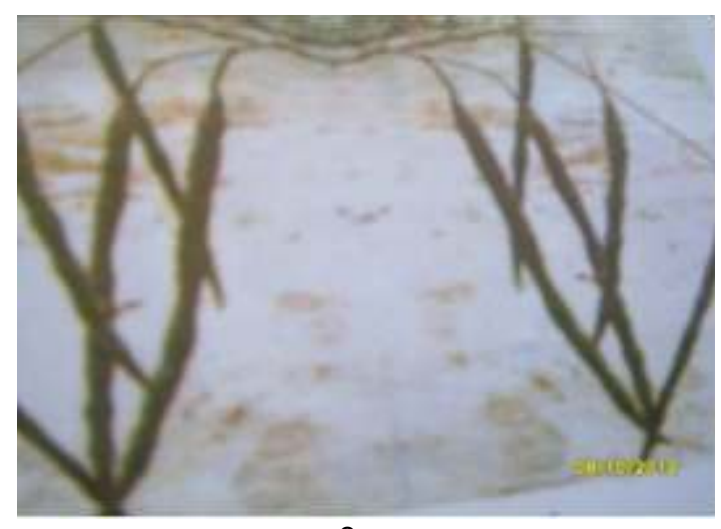

2


6 




7

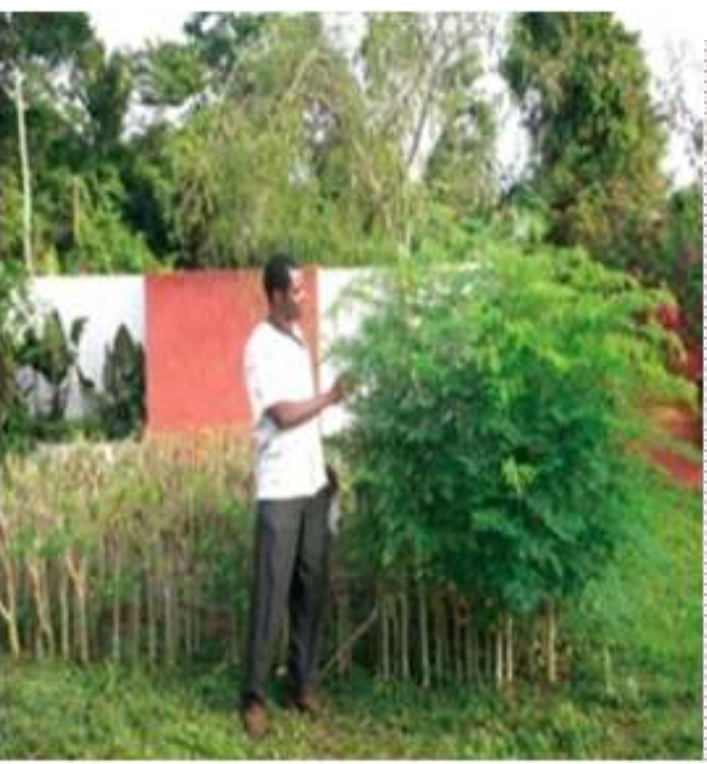

9

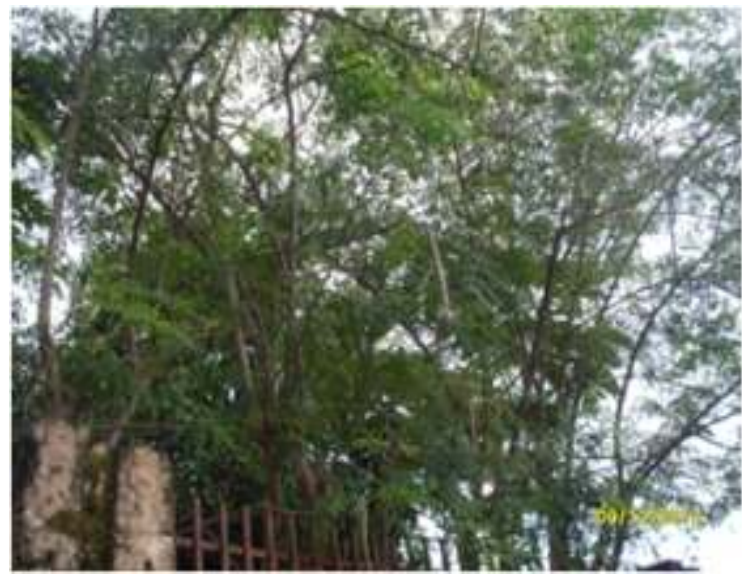

8



10

Plates 1-10: (1) Agroforestry-Taungya systems for food production (2) Seedlings Production Stage of Moringa oleifera at FRIN Nursery, Ibadan, Nigeria, (3) Pods and seeds cake: purify water, treat tooth ache from tooth decay, expel worms, treat problems of the liver and spleen, and relieve joint pain (4) Prominent example of the taungya, agroforestry include systems of healthy seedling tree of Moringa oleifera crop combinations under Pinus caribea Plantation, FRIN agroforestry experimental plot Ibadan, Nigeria Photo: C. Ajayi), (5) Ounce per Ounce leaves of Moringa oleifera, (6) Leaf powder (an excellent source of Vitamin E, tocopherol acetate, for DNA and sexual development Photo: I. Lawal), (7) Moringa Silk Body Butter (8) traditional growing of Moringa oleifera as hedges around houses fencing are among the practices observed in llorin, Kwara, 
Nigeria Photo: C. Ajayi), (9) systematic increasing over-exploitation of Moringa oleifera (foreground) and mixtures of incorporation of indigenous species diversity advocated by agroforestry practice of which taungya is an integral part in the rear (Moringa Plantation, University of Ilorin, Kwara, Nigeria; Photo: F. Babalola) and (10) High Human Pressure by high demand for food, medicine and feed stock from potential buyers found in individuals for consumption, herbal doctors, poultry and pig farmers further give credence to Moringa oleifera as a commercial tree species and its suitability for forest management intervention in Taungya farming system in India (Photo: A. de Saint-Sauveur).

Despite such improved income estimates for the taungya farmer, Olawoye (1975) contended that the living conditions of the traditional taungya farmers have not improved as compared to those of other rural villagers. In contrast, the departmental taungya farmer has enjoyed substantial benefits in terms of provision of infrastructure and other amenities. The indication is that, although a low standard of living is required as a prerequisite for the introduction of taungya, its continued successful development depends on the extent to which it improves the standard of living of the farmer. As long as improvement does not occur, the capable farmer will look to the urban centres in search of a better living standard, the practice of taungya being left to less efficient hands.

From the seedlings to growing those for research and commercial purposes as newly discovered money spinning miracle plant, the usefulness of Moringa Oleifera ranges from a lot of people that are cultivating moringa commercially now. But Nigerians are still very far behind nations like Ghana, Senegal, etc. Research has shown that Moringa Oleifera alongside others such as castor and Jatropha are all bio diesel that are commercial plants of great international value. As these trees grow, the farmers are expected to move on, after obtaining several harvests from their crops. Taungya systems embrace multiple land-use practices involving joint production of forestry and agricultural crops in the tropics, land is a most important factor of production and there is overwhelming dependence of the population on land for livelihood. The introduction of taungya has alleviated the problems created by the wasteful use of land under the traditional agricultural production systems, increased food supplies, and significantly contributed to the socio-economic well-being of the rural population. One of the alternatives to shifting cultivation is the taungya system of large-scale forest plantation establishment used by forest departments, in which food crops are interplanted with trees in the early years of the plantation.

\section{Economic Implication(s)}

As pressures on agricultural land base increase, leading to progressive fragmentation of farm holdings and overuse of arable land, the ability of farm household (e.g. homestead gardens) to achieve self sufficiency from their land has been declining widely. Rural and urban populations are becoming increasingly reliant on farm and non-farm income in order to meet their food and other needs. Products of farm trees can be important sources of farm income (Arnold and Dewees, 1995). A well packaged Moringa powder can also be exported as shown from varying sizes of FRIN Moringa oleifera leaf powder (Plate 6 and 7). In fact, moringa oil is equally something of a well-kept secret among health and beauty professionals. When it comes to anti-aging compounds 
absorbed deep into the skin, it is hard to beat the amazing performance of pure Moringa oil (Osewa, 2012).

The economic implications of the Moringa oleifera (Miracle Tree) will need to be examined at two levels of activities, to include both the extraction of Moringa oleifera (Miracle Tree) and the distributional medicinal usage of Moringa oleifera to urban markets. Why is Moringa's value not yet accepted or used by international agencies like UNICEF, WHO and WFP? The obstacles preventing this acceptance include the fact that Moringa already exists and used in many African countries, it is not difficult to promote added uses of the tree. However, for Moringa to be acceptable for use as a component of national and international nutrition programs, additional studies are needed to confirm its effectiveness and safety. This procedure will need to offer adequate answers to likely research questions such as for example: how were the seeds collected and pre-treated? When were the seeds planted? How many were planted in each bed or pot? How many of the seeds germinated and how long after they were planted? How much water did the seedlings receive? Were they treated with insecticides or any other chemicals? These are basic rhetorical questions that must be urgently addressed to give further credence to related studies on usefulness of Moringa oleifera tree to make good live fence, leaf/pod vegetables, root powder spice, oil seeds, etc.

\section{CONCLUSION}

On the whole, it is important to start with the planting of the moringa trees as the starting point in the economy of production especially if they are grown for commercial use. On the other hand, a homestead farmer can plant moringa trees any time of the year because they can easily be watered. Growing and processing moringa leaves would require an illustrated guidebook that should contain the emphasis on Cultivation; Harvesting and transportation; Processing the leaves; Packaging and Storage; and using Moringa leaves for nutrition.

The standards, together with a code of good practices and an inspection guide, should be adhered to guaranty the good sanitary and nutritional status of the product especially for moringa leaf powder while emphasizing the need for more clinical studies to obtain acceptance of Moringa as a nutritional food supplement among the international scientific community. Consequent upon the great prospects of farm forestry/ taungya potentials to develop the Moringa oleifera processing and increase value addition, the high land to man ratio factor is yet to be addressed. It is recommended that taungya-combined production of forestry and moringa tree /agricultural crops on forest lands be advocated. The taungya system always exhibited certain basic attributes and required some preconditions for its adoption. The preconditions, such as land hunger and low standard of living of the population, are clearly socio-economic in nature. There is little economic validation of the farming systems described herein. Socioeconomic considerations should however be of high priority on any further research agenda. Evaluation of social acceptability of these practices by farmers should be a major consideration in the process of technology generation. Although numerous studies have been conducted on the Moringa oleifera, few address the social role of the resource, and its contribution to the reduction of the rural poverty. 
Therefore, a cursory look on the leading edge perspectives, science and application in terms of economic potentials of Moringa oleifera as a commercial tree species generally is encouraged for further research studies Nigeria.

\section{REFERENCES}

Adebayo, O., Akinyemi, O. and Ojo, M.O (2004). "Cultivation, Marketing and Utiization of Vernomia amydalina in Ibadan". Journal of Forest Research Management, 1\& 2:35-37.

Adedire, M. O. (2013). "FWM 314: Principles of Agroforestry." Af lecture note - The Federal University of Agriculture, Abeokuta http://www.unaab.edu.ng/.../465_AF\%20LECTURE\%20NOTE.pdf 18/03/13.

Agrawal, A. K., Joshi, A. P.; Kandwal, S.K. and Dhasmana, R. (1986). "An ecological analysis of Malin Riverain forest of outer Garhwal Himalaya (western Himalaya)". Indian Journal of Ecology 13(1): 15-21.

Anadu, P. A. and Oates, J. F. (1982). "The Status of Wildlife in Bendel State, Nigeria with Recommendations for its Conservation." In: Report to the Bendel State Ministry of Agriculture and Natural Resources, the Nigerian Federal Ministry of Agriculture, the Nigerian Conservation Foundation, the New York Zoological Society, and the World Wildlife Fund (U.S.).

Annual Report (2008). "Jatropha Unit in Forest products Development and Utilization Department (FPD\&U)". In: Forestry Research Institute of Nigeria(FRIN), 2008 Annual Report. 56p

Arnold, J. E. M and Dewees, P. A. (1995). "Tree management in farmer strategies: responses to agricultural intensification." Oxford University Press, Oxford. 292pp

Booth, F. E. M. and Wickens, G. E.(1988) "Non-timber uses of selected arid zone trees and shrubs in Africa." FAO Conservation Guide 19". Rome: Food and Agriculture Organization. 176pp.

Champion, H. G. (1936). "Indian Forest Records 1: A preliminary survey of forest types of India and Burma". 286pp. New Delhi: Government of India Press.

Enabor, E. E., Okojie, J. A. and Verinumbe, I. (1982). "Taungya systems: Socio-economic prospects and limitations". In: Agro-forestry in the African Humid Tropics, UNU, (1982). Pp 162 
FAO (2011). Food and Agriculture Organization. "Forests for improved nutrition and food security". Rome. www.fao.org/docrep/014/i2011e/i2011e00.pdf Last Updated: June 17, 2012

Jahn, S. A, Musnad, H. A. and Burgstaller, H. (1986). "The tree that purifies water: cultivating multipurpose Moringaceae in the Sudan". Unasylva.38 (2): 23-28.

Morton, J.F. (1991) "The horseradish tree, Moringa pterygosperma (Moringaceae)-A boon to arid lands?" Economic Botany. 45(3): 318-333.

Nambair, V. S., Bhadalkar, K. and Daxini, M. (2003) "Drumstick leaves in the ICDS-SFP." Indian Journal of Peadiatrics 70 (5):11-15.

National Population Commission (2006) "National Population Census". Abuja, Nigeria. Nautiyal, B.P. and Venhataraman, K.G. (1987) "Moringa (Drumstick)-An ideal tree for social forestry.1: Growing conditions and uses". Myforest 23(1):53-58.

Oates, J. F. (1999) “Myth and Reality in the Rainforest." Berkeley, University of California Press.

Odeyinka, S. M., and Ajayi, D. A. (2004) "A Survey of Feedstuff for Goats in Osun State". Tropical Journal of Science 7:161-8.

Olawoye, O. O. (1975). "The agri-silvicultural system in Nigeria". Commonw. For Rev., 54 (3/4): 229-236.

Osewa, O. (2012) "Moringa Oleifera- Its Medicinal, Nutritional and Socio-Economic ImportanceHealth-Nairaland". Accessed at http://www.nairaland.com/870471/moringa-oleiferamedicinal-nutritional-socio-economic .Stats: 932798 members, 952323 topics.

Parotta, J. A. (1993). "Literature review on Moringa oleifera" http://www. Moringanews.org/documents/review.pdf.SO-ITF-SM-61

Seshadri, S. and Nambiar, V. S. (2003) "Kanjero (Digera arvensis) and Drumstick leaves (Moringa oleifera): Nutrient profile and potential for Human consumption". In: plants in Human Health and Nutrition policy. World Review of Nutrition and Dietetics Basel, Karger. . 91: 41-56.

Torimiro, D .O., Odeyinka, S. M., Okorie, V. O. and Akinsuyi, M. A. (2009) "Gender Analysis of Socio-Cultural Perception of Moringa Oleifera Amongst Farmers in Southwestern Nigeria." Journal of International Women's Studies. Vol. 10 (4): 188-202. 
Appendix I

Number and proportion of respondents and their perception of Moringa oleifera

\begin{tabular}{|c|c|c|c|c|c|c|c|c|c|c|}
\hline \multirow{2}{*}{$\begin{array}{l}\text { Perceptional } \\
\text { Statements } \\
\text { on Moringa } \\
\text { oleifera }\end{array}$} & \multicolumn{5}{|l|}{ Male } & \multicolumn{5}{|l|}{ Female } \\
\hline & S.A & A & U & D & SD & S.A & $A$ & U & $\mathrm{D}$ & SD \\
\hline $\begin{array}{l}\text { 1- There is } \\
\text { nothing } \\
\text { special about } \\
\text { the crop }\end{array}$ & $\begin{array}{l}0 \\
(30.7)\end{array}$ & $\begin{array}{l}3 \\
(39.3)\end{array}$ & $\begin{array}{l}17 \\
(25.0)\end{array}$ & $\begin{array}{l}22 \\
(5.4)\end{array}$ & $\begin{array}{l}14 \\
(3.6)\end{array}$ & $\begin{array}{l}3 \\
(75.0)\end{array}$ & $\begin{array}{l}2 \\
(3.6)\end{array}$ & $\begin{array}{l}42 \\
(12.5)\end{array}$ & $\begin{array}{l}2 \\
(0.0)\end{array}$ & $7(5.4)$ \\
\hline $\begin{array}{l}2 \text { - The crop is } \\
\text { very } \\
\text { dangerous }\end{array}$ & $\begin{array}{l}0 \\
(21.8)\end{array}$ & $\begin{array}{l}0 \\
(0.0)\end{array}$ & $\begin{array}{l}14 \\
(0.0)\end{array}$ & $\begin{array}{l}31 \\
(25)\end{array}$ & $\begin{array}{l}11 \\
(55.4)\end{array}$ & $\begin{array}{l}0 \\
(19.6)\end{array}$ & $\begin{array}{l}0 \\
(0.0)\end{array}$ & $\begin{array}{l}38 \\
(0.0)\end{array}$ & $\begin{array}{l}5 \\
(69.1)\end{array}$ & $\begin{array}{l}13 \\
(9.1)\end{array}$ \\
\hline $\begin{array}{l}3+\text { The } c \text { rop } \\
\text { is of great } \\
\text { economic } \\
\text { importance }\end{array}$ & $\begin{array}{l}0 \\
(0.0)\end{array}$ & $\begin{array}{l}3 \\
(5.4)\end{array}$ & $\begin{array}{l}23 \\
(41.4)\end{array}$ & $\begin{array}{l}30 \\
(54.0)\end{array}$ & $\begin{array}{l}0 \\
(0.0)\end{array}$ & $\begin{array}{l}54 \\
(95.4)\end{array}$ & $\begin{array}{l}0 \\
(0.0)\end{array}$ & $\begin{array}{l}2 \\
(3.6)\end{array}$ & $\begin{array}{l}0 \\
(0.0)\end{array}$ & $\begin{array}{l}0 \\
(0.0)\end{array}$ \\
\hline $\begin{array}{l}\text { 4- We cannot } \\
\text { plant the crop } \\
\text { in our } \\
\text { community }\end{array}$ & $\begin{array}{l}0 \\
(14.3)\end{array}$ & $\begin{array}{l}2 \\
(0.0)\end{array}$ & $\begin{array}{l}1 \\
(3.6)\end{array}$ & $\begin{array}{l}42 \\
(1.8)\end{array}$ & $\begin{array}{l}11 \\
(75.0)\end{array}$ & $\begin{array}{l}0 \\
(19.6)\end{array}$ & $\begin{array}{l}0 \\
(0.0)\end{array}$ & $\begin{array}{l}19 \\
(0.0)\end{array}$ & $\begin{array}{l}29 \\
(33.9)\end{array}$ & $\begin{array}{l}8 \\
(51.8)\end{array}$ \\
\hline $\begin{array}{l}5 \text { - The crop } \\
\text { will be too } \\
\text { expensive to } \\
\text { plant in our } \\
\text { village }\end{array}$ & $\begin{array}{l}0 \\
(0.0)\end{array}$ & $\begin{array}{l}0 \\
(7.2)\end{array}$ & $\begin{array}{l}4 \\
(65.3)\end{array}$ & $\begin{array}{l}36 \\
(19 . \\
6)\end{array}$ & $\begin{array}{l}11 \\
(36.0)\end{array}$ & $\begin{array}{l}20 \\
(0.0)\end{array}$ & $\begin{array}{l}0 \\
(54.0)\end{array}$ & $\begin{array}{l}30 \\
(10.0)\end{array}$ & $\begin{array}{l}6 \\
(0.0)\end{array}$ & $\begin{array}{l}0 \\
(0.0)\end{array}$ \\
\hline $\begin{array}{l}6+\text { The crop is } \\
\text { of great } \\
\text { cultural value } \\
\text { in our } \\
\text { community }\end{array}$ & $\begin{array}{l}0 \\
(41.4)\end{array}$ & $\begin{array}{l}3 \\
(54.0)\end{array}$ & $\begin{array}{l}23(0.0 \\
)\end{array}$ & $\begin{array}{l}30 \\
(90.0)\end{array}$ & $\begin{array}{l}0 \\
(10.0)\end{array}$ & $\begin{array}{l}50 \\
(0.0)\end{array}$ & $\begin{array}{l}6 \\
(0.0)\end{array}$ & $\begin{array}{l}0 \\
(0.0)\end{array}$ & $\begin{array}{l}0 \\
(0.0)\end{array}$ & $\begin{array}{l}0 \\
(5.4)\end{array}$ \\
\hline $\begin{array}{l}7+\text { The crop } \\
\text { has medicinal } \\
\text { value }\end{array}$ & $\begin{array}{l}1 \\
(1.8)\end{array}$ & $\begin{array}{l}5 \\
(9.0)\end{array}$ & $\begin{array}{l}25 \\
(45.0)\end{array}$ & $\begin{array}{l}24 \\
(43.0)\end{array}$ & $\begin{array}{l}1 \\
(1.8)\end{array}$ & $\begin{array}{l}45 \\
(80.2)\end{array}$ & $\begin{array}{l}10 \\
(18)\end{array}$ & $\begin{array}{l}1 \\
(1.8)\end{array}$ & $\begin{array}{l}0 \\
(0.0)\end{array}$ & $\begin{array}{l}0 \\
(0.0)\end{array}$ \\
\hline $\begin{array}{l}\text { 8- The crop is } \\
\text { of no value at } \\
\text { all }\end{array}$ & $\begin{array}{l}0 \\
(1.8)\end{array}$ & $\begin{array}{l}2 \\
(75.0)\end{array}$ & $\begin{array}{l}1 \\
(19.6)\end{array}$ & $\begin{array}{l}42 \\
(5.4)\end{array}$ & $\begin{array}{l}11 \\
(0.0)\end{array}$ & $\begin{array}{l}3 \\
(0.0)\end{array}$ & $\begin{array}{l}0 \\
(0.0)\end{array}$ & $\begin{array}{l}0 \\
(50.6)\end{array}$ & $\begin{array}{l}0 \\
(0.0)\end{array}$ & $\begin{array}{l}53 \\
(3.6)\end{array}$ \\
\hline $\begin{array}{l}\text { 9- Farmers in } \\
\text { this } \\
\text { community } \\
\text { will never } \\
\text { plant the crop }\end{array}$ & $\begin{array}{l}0 \\
(41.4)\end{array}$ & $\begin{array}{l}30 \\
(5.4)\end{array}$ & $\begin{array}{l}23 \\
(0.0)\end{array}$ & $\begin{array}{l}3 \\
(0.0)\end{array}$ & $\begin{array}{l}0 \\
(0.0)\end{array}$ & $\begin{array}{l}0 \\
(33.9)\end{array}$ & $\begin{array}{l}0 \\
(51.8)\end{array}$ & $\begin{array}{l}19 \\
(14.3)\end{array}$ & $\begin{array}{l}29 \\
(0.0)\end{array}$ & $\begin{array}{l}8 \\
(54.0)\end{array}$ \\
\hline $\begin{array}{l}\text { 10+ Farmers } \\
\text { in our } \\
\text { community } \\
\text { will adopt } \\
\text { innovation on } \\
\text { Moringa }\end{array}$ & $\begin{array}{l}3 \\
(41.4)\end{array}$ & $\begin{array}{l}23 \\
(54.0)\end{array}$ & $\begin{array}{l}30 \\
(0.0)\end{array}$ & $\begin{array}{l}0 \\
(95.4)\end{array}$ & $\begin{array}{l}54 \\
(0.0)\end{array}$ & $\begin{array}{l}0 \\
(3.6)\end{array}$ & $\begin{array}{l}2 \\
(0.0)\end{array}$ & $\begin{array}{l}0 \\
(0.0)\end{array}$ & $\begin{array}{l}0 \\
(0.0)\end{array}$ & $\begin{array}{l}0 \\
(5.4)\end{array}$ \\
\hline
\end{tabular}

